International Journal of Current Microbiology and Applied Sciences

ISSN: 2319-7706 Volume 6 Number 8 (2017) pp. 2636-2642

Journal homepage: http://www.ijcmas.com

Original Research Article

https://doi.org/10.20546/ijcmas.2017.608.313

\title{
In Vitro Antifungal Activities of Common Weed Extracts on Mycelial Growth of Alternaria solani (Ell. and Martin) Jones and Grout
}

\author{
Jaskaran Singh ${ }^{1}$, S.K. Biswas ${ }^{2}$, Devesh Nagar ${ }^{1}$, Ravindra Singh ${ }^{1}$ and Morajdhwaj Singh ${ }^{1}$ \\ ${ }^{1}$ Department of Plant Pathology, Sardar Vallabh Bhai Patel University of Agriculture and \\ Technology, Meerut, Uttar Pradesh, India \\ ${ }^{2}$ Department of Plant Pathology, Chandra Shekhar Azad University of Agriculture and \\ Technology, Kanpur, Uttar Pradesh, India \\ *Corresponding author
}

\section{A B S T R A C T}

Herbal fungicides are mostly used to control plant disease because of their

Keywords

In vitro,

Antifungal

Activities,

Alternaria solani.

Article Info

Accepted:

21 June 2017

Available Online:

10 August 2017 eco-friendly nature and cost effectiveness. The present investigation focuses on the antifungal activity of some weed extracts viz., Salix sp., Achyranthus aspera, Solanum nigrum, Parthenium hysterophorus, Datura fastusa, Melilotis alba, Lantana camara, and Achyranthus aspera,. Out of 8 weed tested, the extracts of Datura, Parthenium, Achyranthus, Salix sp. and Physallis minima were found most effective against phytopathogenic fungi, Alternaria solani. The antifungal activity of these plant extract was determined in vitro following Poison Food Technique. The results are showed that maximum inhibition was obtained by Datura extract (80.78 reduction) followed by Parthenium (76.48), Achyranthus (69.66), Salix sp. (65.14) and Physallis minima (49.53). The other treatments were also significantly controlled the mycelium growth of Alternaria solani.

\section{Introduction}

Tomato (Lycopersicon esculentum Mill). Belongs to the family Solanaceae and is one of the most remunerable and widely grown vegetables in the world. Among vegetable crop, tomato ranks second important vegetable in the world next to potato and first among the processing crops.

The productivity of tomato in India is 20.7 MT/ha during 2012-13 which is very low as compare to other country of the world like USA, 81.0 tones /ha. One of main reason of low productivity of tomato in India is disease which is caused by fungi, bacteria, virus, nematode and abiotic factors (Balanchard, 1992). Among the fungal diseases, early blight also known as target spot disease incited by Alternaria solani (Ellis and Martin) Jones and Grout is one of the world's most catastrophic disease. The pathogen is air and soil borne in nature and is responsible to cause disease as early blight, collar rot and fruit rot etc (Datar and Mayee, 1981). 
Spraying of broad spectrum fungicides like mancozeb, captan and Paraclostrobin (25\%), copperoxychloride, chlorothalonil has been recommended for the control of early blight of tomato by several workers (Ramakrishnan et al., 1971 and Stevenson, 1977) and (chethana, 2009 and sahu et al., 2013).

Cultural practices like field sanitation, deep summer ploughing, soil solarization, soil amendment, crop rotation etc. can be minimized the possibility of disease but cannot completely control the disease on standing crop. Biological control is another important method of plant disease management. In this content, Trichoderma sp. Gliochodium virens, Chaetomium globosum, Aspergillus niger AN 27, Pseudomonas fluorescens etc. have been exploited for management of plant diseases (Biswas et al., 2003, Girdhari lal et al., 2008, Razic et al., 2012, Butler, 1905). However, slight fluctuation of temperature, relative humidity, $\mathrm{pH}$, moisture largely affects the efficacy of bioagents. Therefore, the use of chemicals is one of the best methods of plant disease management. Several fungicides Mancozeb, propineb, metalaxyl, foretyl-Al, aureofungin, streptocycline, phosphonic acid, and chlorthanil @ 0.2\% and Iprovalicarb + propineb for seed treatment have been used for management of Alternaria blight of tomato (Chaudhari et al., 2002 and Andreu and Coldiz 2006).

However, continuous use of same chemicals is not advisable for management of plant diseases, because of development of resistance strains among the pathogens.

It has also hazardous to human health and environment. Therefore, there is a need to search for on alternate methods for management of plant disease in sustainable agriculture. In this content use of plant products has been great attention in plant disease management. (Arzoo at al. (2013). reported that use of plant extracts Neem, Dhatura, Zinger, Garlic, Mutha etc. as seed treatment increases. Plant growth and decreases seedling mortality of tomato causes by Fusarium wilt. Zarina et al., (2003) also found that soil amendment with extract of neems and dhatura increases the growth of bringal plant and also controlled infestation of root knot nematodes.

\section{Materials and Methods}

The materials used and methods adopted in laboratory and glass house experiment was undertaken at Department of Plant Pathology, C.S.A. University of Agriculture and Technology, Kanpur.

\section{Collection of plant materials for preparation of extract}

The plant materials like. (Salix sp., Achyranthus aspera, Solanum nigrum, Parthenium hysterophorus, Datura fastusa, Melilotis Alba, Lantana camara and Achyranthus aspera) were collected from vicinity area of University campus for extraction and further use in bioassay test against pathogen.

\section{Preparation of plant extract}

The fresh and mature leaves of collected plant materials were thoroughly washed under running clean tap water to remove dust and other surface contaminant. The extract was obtained from individual plant material by electric mixie in distilled water 1:1 (w/v). The resultant slurry was strained through a double layered muslin cloth to remove the uncrushed fibrous tissue of plant material. The procedure repeated twice and each time, the resultant slurry was filtered through two fold muslin cloth. The final volume of the filtrate thus obtained was made up to one liter by adding 
water to maintain at ten percent concentration on fresh weight basis of plant material (w/v).

\section{Antifungal activity of plant extracts}

Anti-fungal activity of plant extracts was determined by Poison food technique (Kumar and Tyagi 2013; Mohanta and Raveesha 2007).The prepared plant extracts were poured in conical flask containing tomato extract media in 1:5 (v/v) ratios. The poisoned media was later autoclaved at $15 \mathrm{psi}$ and $121.6^{\circ} \mathrm{C}$ temperature for 20 minutes.

\section{Inoculation of pathogen}

The autoclaved media containing plant extracts was poured in sterile Petri plates under aseptic conditions. After solidification of media $10 \mathrm{~mm}$ diameter mycelia discs cut from periphery of actively growing pure culture of the pathogen (A. solani), was placed at the centre of each Petri plate.

Three replications were maintained for each treatment and tomato extract media without any treatment served as control. Petri plates were incubated at $28{ }^{\circ} \mathrm{C}$ and mycelia growth was measured at every $24 \mathrm{hrs}$ interval upto 7 days.

In-vitro evaluation of plant extracts on radial growth of fungal colony

Two replicates of $5-\mu \mathrm{L}$ aliquots of the plant extracts were placed $90^{\circ}$ apart on the perimeter of each of two Petri dishes each (9 $\mathrm{cm}$ in diameter) of potato dextrose media. Petri dishes were incubated overnight at room temperature. A 5-mm plug of A. solani was transferred to the center of each tomato extract medium Petri dish.

The Petri dishes were incubated at $20^{\circ} \mathrm{C}$ and duplicate diameters of fungal colonies were measured at $90^{\circ}$ with a ruler when the control colony reached full growth $(85 \mathrm{~mm})$. This occurred 7 days after incubation on potato dextrose media.

\section{Results and Discussion}

\section{Effect of plant extracts on mycelial growth of Alternaria solani in vitro}

Natural products from many plants are known to control plant pathogens. Antifungal activity testing of weeds remains an area of interest. However not many reports are available on the exploitation of antifungal property of weeds plants and even the data regarding use of weeds as an antifungal agents are scanty, (Shivastava and Singh, 2011).

The antimicrobial potency of plants is believed to be due to tannis, saponins, phenolic Compounds, essential oils and flavonoids, (Tapwal et al., 2011). The antimicrobial activity of plant oils and extracts has formed the basis of many applications, including raw and processed food preservation, pharmaceuticals, alternative medicine and natural therapies, (Lis-Balchin and Deans, 1997).

The results of in vitro antifungal activity of 8 plant extracts are summarized in table 1 . The extracts produced different levels of antifungal activity against $A$. solani. Results indicated that all the extracts significantly reduced the radial growth of $A$. solani, in comparison with the control. The antifungal activity of different plant extract was determined in vitro following Poison Food Technique. The results are presented in table 1 shows that maximum inhibition was obtained by Datura extract (80.78 reduction) followed by Parthenium (76.48), Achyranthus (69.66), Salix sp. (65.14) and Physallis minima (49.53) (Fig. 1). The other treatments were also significantly controlled the mycelium growth of Alternaria solani. Thus, 
the extract of, Datura and Parthenium could be a possible source to obtain new and effective biofungicides to control $A$. solani in various crops. Biofungicides are easily biodegradable, selective and locally produced, especially for the farmers who cannot afford expensive synthetics fungicides. By using weed plant species as raw materials for plant derived fungicides, can manage the disease, and at the same time might create economic uses for these unwanted species (Shivastava and Singh, 2011).

Table.1 Effect of plant extracts on the mycelial growth of Alternaria solani

\begin{tabular}{|l|c|c|}
\hline \multicolumn{1}{|c|}{ Treatment } & Colony diameter $(\mathbf{m m})$ & Reduction against control \\
\hline Melilotis alba & 68.56 & 14.34 \\
\hline Solanum nigram & 71.87 & 11.45 \\
\hline Physallis minima & 46.86 & 49.37 \\
\hline Salix sp. & 28.32 & 64.71 \\
\hline Datura fastusa & 14.59 & 80.68 \\
\hline Convolvulus arvensis & 62.18 & 24.57 \\
\hline Achyranthus aspera & 25.00 & 69.47 \\
\hline Parthinium hysterophorus & 19.56 & 76.75 \\
\hline Control-1 & 81.00 & - \\
\hline Control-2 & 81.46 & - \\
\hline S.E. & 2.456 & - \\
\hline C.D. $(\mathrm{P}=0.05)$ & 1.177 & - \\
\hline
\end{tabular}

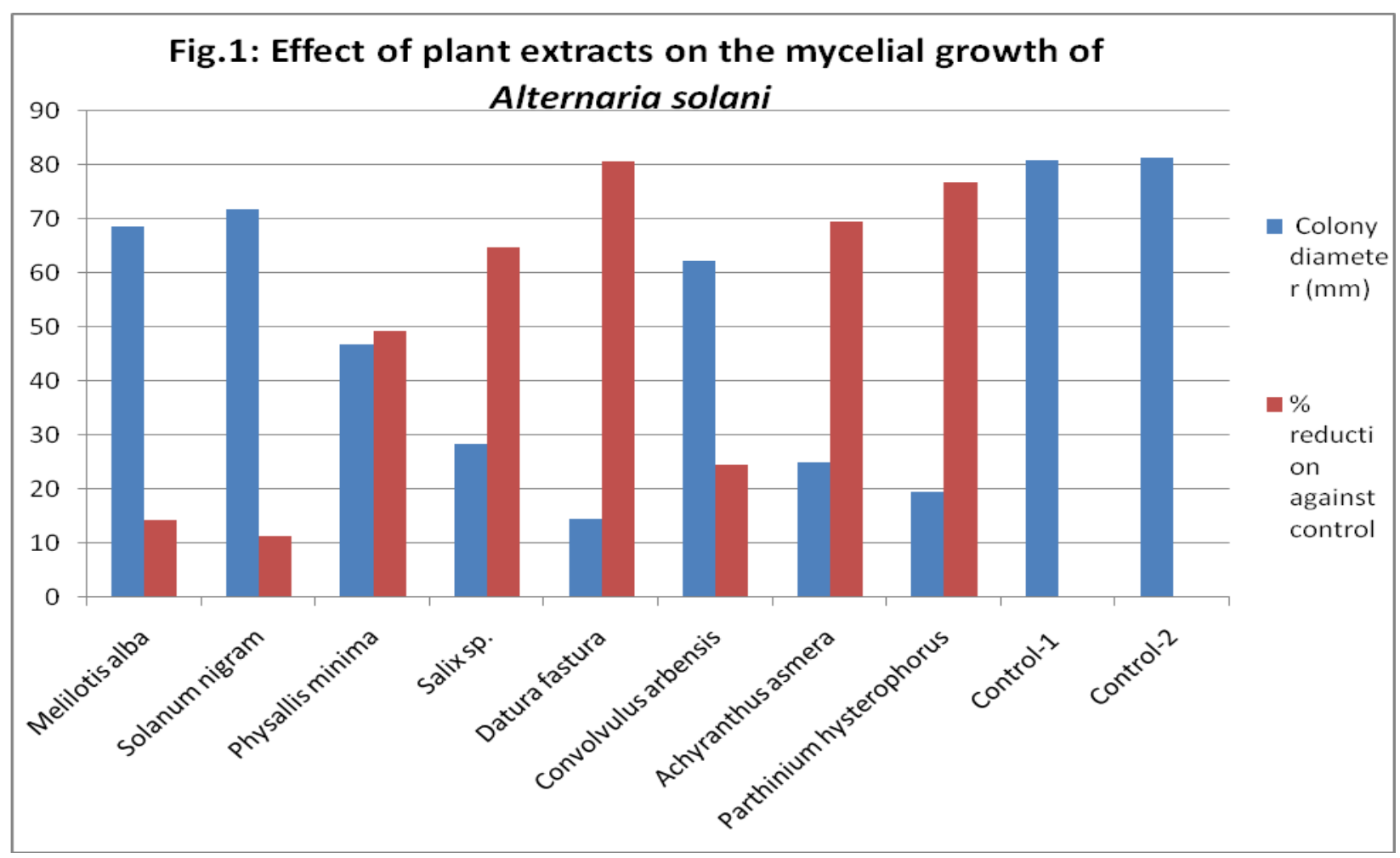


Present findings also supported by Jalender and Gachande (2012) the leaf extract of $D$. stramonium and D. innoxia at $20 \%$ concentration was found more inhibitory activity against $F$. oxysporum udum, while the extract of D. stramonium at $20 \%$ concentration was inhibitory against $A$. solani. Shrestha and Tiwari (2009) reported complete inhibition of mycelial growth of Fusarium solani (Mart.) Sacc. Causing dry potato tuber rot when treated with Allium sativum extract. The inhibitory effect of Salix sp. (willow) aqueous extract against Alternaria solani could be explained by the presence of salicin i.e. glucoside of salicyl alchohol. Salicin may bind with receptors on the surface of pathogen cells and penetrates to the fungal cells which could be killed through denaturation of some enzymes and proteins. Salicin may be the major compound that shows the antifungal effect but other metabolites may increase the potency of the Salix sp. (willow) extracts compared with pure salicin (El-Shemy et al., 2007). Pal and Kumar (2013) also reported invitro mycelia inhibition of Fusarium with Achyranthes aspera and Parthenium hysterophorus extracts.

In order to maintain the productivity, more and more chemicals are being added in the natural environment, which enter the food chain through water, soil, and air resulting serious harmful effects on human health (Ramachandra et al., 2003). According to the survey made by the WHO, more than 50,000 people in developing countries are annually poisoned and 5,000 die as a result of the effects of toxic agents, used in agriculture. In India 35,000 - 40,000 tons of hazardous chemicals are sprayed on the crops every year, instead of helping the poor, these chemicals are causing cancer, sterility and death (Das, 1983).

To avoid the use of these horrible diseases causing synthetic chemicals, the plants and their products should be utilized to combat phytopathogens. As plants are known to possess various secondary metabolites, which showed inhibitory effect against the growth of pathogens. Keeping these problems in view, efforts are underway to search economic safe phytochemicals, which could be utilized for disease control.

\section{References}

Gurjar, M.K., Shahid Ali, Masood Akhtar, Kangabam Suraj Singh, 2012. Efficacy of plant extracts in plant disease management. Agricultural Sciences, 3: 425-433.

Enyiukwu D. N., Awurum A. N., Ononuju C. C. and Nwaneri J. A., 2014. Significance of characterization of secondary metabolites from extracts of higher plants in plant disease management. International Journal of Advanced Agricultural Research. 8 (28): 2053-1265.

El-Shemy, H.A., Aboul-Enein, A.M., AboulEnein, K.M., Fujita, K., 2007. Willow Leaves' Extracts Contain Anti-Tumor Agents Effective against Three Cell Types. PLoS ONE 2 (1), e178.

Srivastava D, Singh P, 2011. Antifungal potential of two common weeds against plant pathogenic fungi Alternaria sps, Asian J Exp Bio Sci. 2(3): 525-528.

Reynolds JEF, Martindale, 1996. "The Extra Pharmacopoeia", 31st edition London, Royal Pharmaceutical Society of Great Britian,

Enyiukwu D. N., Awurum A. N., Ononuju C. C. and Nwaneri J. A., 2014. Significance of characterization of secondary metabolites from extracts of higher plants in plant disease management. International Journal of Advanced Agricultural Research. 8 (28): 2053-1265.

Ganie, S.A., Gahani, M.Y., Nissar Qazi and 
Shabir- Ur- Rehman., 2013. Bioefficacy of plant extracts and biocontrol agents against Alternaria solani. African Journal of Microbiology Research. 34: 4397-4402.

Gurjar, M.K., Shahid Ali, Masood Akhtar, Kangabam Suraj Singh, 2012. Efficacy of plant extracts in plant disease management. Agricultural Sciences. 3: 425-433.

Hanna Farag R.M., Abdou Zeinab A., Salama Dalawat A., Ibrahim Mervat A.R., Sror H.A.M., 2011. Effect of neem and willow aqueous extracts on Fusarium wilt disease in tomato seedlings: Induction of antioxidant defensive enzymes. Annals of Agricultural Science. 56: 1-7.

Jalander V, Gachande, B.D., 2012. Effect of Aqueous Leaf Extracts of Datura sp. Against Two Plant Pathogenic Fungi. International Journal of Food, Agriculture and Veterinary Sciences. ISSN: 2277-209X.

Kavitha, H.U. and Satish, S., 2011. Ecofriendly management of plant pathogens by some medicinal plant extracts. Journal of Agricultural Technology. 7(2): 449-461.

Khan M, Srivastava SK, Shyamsundar KV, Singh M, Naqvi AA, 2002. Chemical composition of leaf and flower oil of Lantana camara from India. Flavour and Fragrance Journal 17: 75-77.

Lin Tsung-Chun, Mi-Chen Fan, Sheng-Yang Wang and Jenn-Wen Huang. 2011. Identification of the Solanum nigrum Extract Component Involved in Controlling Cabbage Black Leaf Spot Disease. J. Agric. Food Chem. 59: 1667-1672

Maharajan, B.L., Shrestha, K. and Bansyat, S, 2010. Botanical control of late blight of potato. Nepal Journal of Science and Technology 11: 37-40.

Lis-Balchin M, Deans SG, 1997. "Bioactivity of selected plant essential oils against Listeria monocytogenes (L.)”, J. of Appl. Bacteriol, 82:759-762.

Ramachandra TV, Nagarathna AV, 2003 Eco degradation, Biodiversity and Health, Current Science 85 (6):1368-1369.

Mohanta, D.C. and Raveesha, K.A., 2007. Antifungal evaluation of some plant extracts against some plant pathogenic field and storage fungi. Journal of Agricultural Technology 4(1): 119-137.

Nagassoum MB, Yonkeu S, Jirovetz L, Buchbauer G, Schmaus G, Hammerschmidt FJ, 1999. Chemical composition of essential oils of Lantana camara leaves and flowers from Cameroon and Madagascar. Flavour and Fragrance Journal 14: 245-250.

Pal Gaurav kumar and Kumar Brijesh, 2013. Antifungal activity of some common weed extracts against wilt causing fungi, Fusarium oxysporum. Current Discovery 2: (1) 62-67

Reynolds JEF, Martindale, 1996. "The Extra Pharmacopoeia", 31st edition London, Royal Pharmaceutical Society of Great Britian.

Roy, B., Sarker, B. C., Ali, M.R., Das, S.R. and Sayed M.A.S., 2012. Seed Germination and Seedling Growth of Two Vegetables in Responses to Aqueous Extract of Four Herbal Plant Leaves. J. Environ. Sci. Natural Resources 5(1): 141-150.

Shreshtha Kazi Asha and Tiwari R.D., 2009. Antifungal Activity of Crude Extracts of Some Medicinal Plants against Fusarium solani (mart.) Sacc. ECOPRINT 16: 75-78, 2009.

Singh G, Pandey SK, Leclerq PA, Sperkova J, 2002. Chemical constituents of the leaf oil of Lantana indica Roxb. From north India. Journal of Essential Oil Research 14: 346-347.

Singh G, Srivastava P, Narayanan CS, Padmakumari KP, 1991. Chemical 
investigation of the essential oil of Lantana camara. Indian Perfumer 35: 209-211.

Yusuf Yanar, Izzet Kadioğlu, Ayhan Gökçe1, Đbrahim Demirtas, Nezhun Gören, Halit Çam and Mark Whalon., 2011. In vitro antifungal activities of 26 plant extracts on mycelial growth of Phytophthora infestans (Mont.) de Bary. African Journal of Biotechnology Vol. 10 (14): 2625-2629.
Farag Hanaa R.M., Abdou Zeinab A., Salama Dawlat A., Ibrahim Mervat A.R., Sror H.A.M., 2011. Effect of neem and willow aqueous extracts on Fusarium wilt disease in tomato seedlings: Induction of antioxidant defensive enzymes. Annals of Agricultural Science (56): 1-7.

Das, T. 1983. "Death in the Garb of Pesticides". The Hindustan Times. Dec. 30

\section{How to cite this article:}

Jaskaran Singh, S.K. Biswas, Devesh Nagar, Ravindra Singh and Morajdhwaj Singh. 2017. In Vitro Antifungal Activities of Common Weed Extracts on Mycelial Growth of Alternaria solani (Ell. and Martin) Jones and Grout. Int.J.Curr.Microbiol.App.Sci. 6(8): 2636-2642. doi: https://doi.org/10.20546/ijcmas.2017.608.313 